\title{
Contribution to Genetic Control of Flower Number in Pea (Pisum sativum L.)
}

\author{
Andrey Sinjushin* Anna Liberzon \\ M. V. Lomonosov Moscow State University, Faculty of Biology, 1-12 Leninskie Gory, 119234, Moscow, Russia
}

\begin{abstract}
Summary: Our paper provides new data on genetic control of flower number per axillary inflorescence in garden pea (Pisum sativum L.). This trait is of both agricultural and evolutionary interest. Analysis of crosses enabled us to conclude that, in addition to previously proposed models of monogenic recessive and cumulative polymery, two genes can control a given trait interacting in a mode of dominant epistasis. This means that few-flowered axillary racemes develop in pea plants either if they bear a dominant allele of inhibiting gene $(F N)$ or comprise double recessive homozygotes ( $f n$ fn fna fna). In the second filial progeny, 13:3 ratio can be observed with few-flowered plants prevailing.

Key words: development, epistasis, flowers, genetic control, inflorescences, peas, Pisum
\end{abstract}

\section{Introduction}

In angiosperms, flowers are usually aggregated in specialized groups, inflorescences, which can be either simple (with flowers borne directly on main axis) or compound (with flowers produced on specialized higher-order axes). Genetic control of compound inflorescence ontogeny is weakly studied to date. Legumes (family Fabaceae s.l.) comprise a convenient object for surveys on genetic regulation of compound inflorescence development. Only few genes have been identified to date, mostly in pea (Pisum sativum L.) (Benlloch et al., 2015). In pea, as in many other leguminous species, flowers develop on specialized flower-bearing lateral racemes (I2) while the main stem (I1) proliferates unlimitedly (Figure 1a). These racemes are usually two-flowered in pea. Genetic control of apical meristem activity of I2 is poorly studied. Except for fundamental interest, data on regulation of inflorescence development in pea are of special practical value for breeding new highly productive cultivars. One of aspects of this regulation is control of flower number per I2. This trait was reported as controlled by two polymeric FLOWER NUMBER genes, FN and FNA

\section{Corresponding author:}

asinjushin@mail.ru

Acknowledgement:

The work was partially supported with the Russian Foundation for Basic Research (project no. 15-04-06374).
(Lamprecht, 1947). According to this model, FN FNA plants produce one flower per I2, fn FN $A$ and $F N$ fna develop two flowers, while fn fna homozygotes produce many-flowered I2s. The same trait was also described as controlled by a single gene NEPTUNE with recessive homozygotes developing three and more flowers per I2 (Singer et al., 1999). Some data on genetic control of flower number are available for chickpea, Cicer arietinum L. (reviewed in Benlloch et al., 2015). The given note presents the results of genetic analysis of this feature providing new data on its inheritance.

\section{Materials and Methods}

When examining the germplasm collection of Genetics Dept., we chose the line DTR produced by the All-Russian Research Institute of Vegetable Breeding and Seed Production (Moscow District, Russia). This line is characterized with determinate growth pattern (det det), i.e. I1 is terminated with flower-bearing raceme similar to I2. Besides this, DTR plants produce fewflowered axillary racemes (I2).

To study inheritance of many-flowered I2 pattern, we analyzed five $F_{2}$ progenies from crosses between DTR and other genotypes, which were characterized with inflorescences producing two- along with (rarely) single-flowered I2s (Figure 1b, 1c). The parental forms together with $F_{1}$ and $F_{2}$ progenies were planted on the experimental plot of the S. N. Skadovskii Zvenigorod Biological Station (Western Moscow District, Russia). 

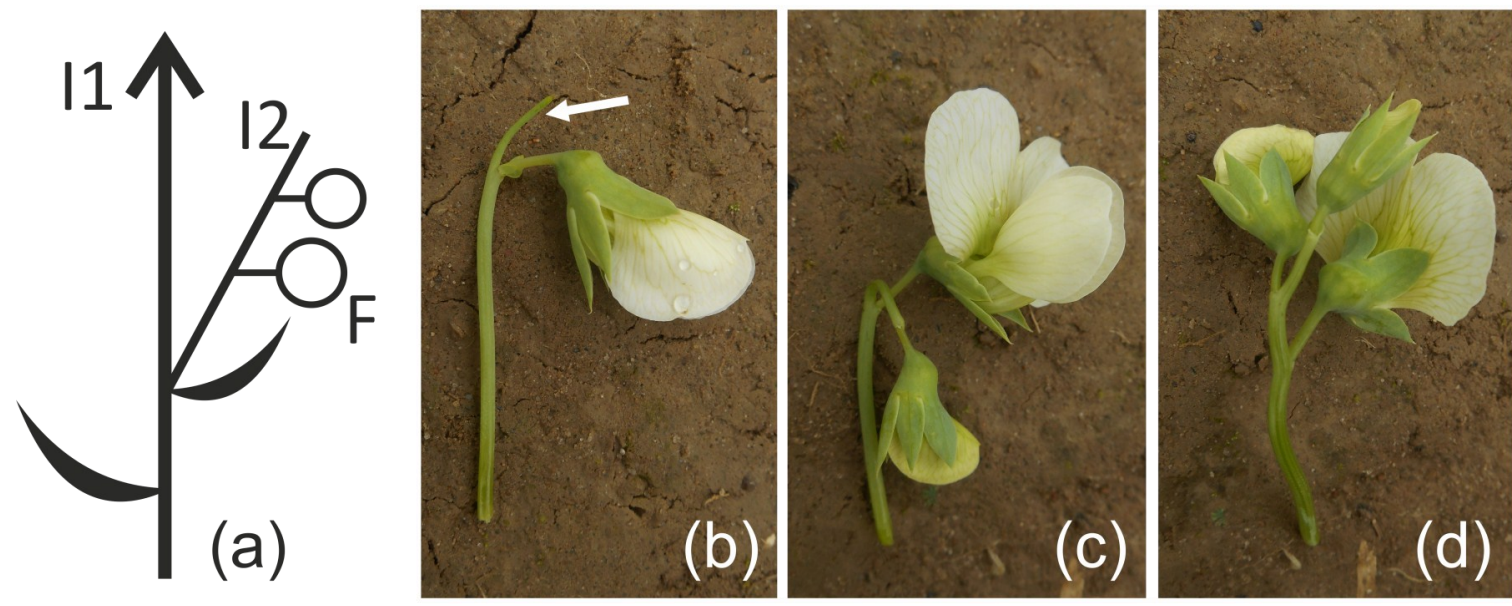

Figure 1. Scheme of pea inflorescence (a) and morphology of I2 in different recombinants: (b) single-flowered with long sterile stub (arrow), (c) two-flowered, (d) three-flowered. F, flower.

\section{Results and Discussion}

$V$ ariations in flower number in the studied lines

In many-flowered line DTR, floral buds on distal portion of I2 usually shed without producing pods, so the resulting seed production is always lower than the potential one. During two field seasons, the average number of opening flowers per I2 was somewhat variable in DTR: $2.79 \pm 0.89$ (average \pm standard deviation in all cases; C.V. $=31.90 \%)$ in 2014, $2.35 \pm$ 0.59 (C.V. $=24.98 \%$ ) in 2015 , and $3.17 \pm 1.58$ (C.V. $=$ $49.82 \%)$ in 2016. These data confirm the existing observations that phenotypic expression of a given trait is dependent on the environmental conditions (Hole \& Hardwick, 1975).

With rare exceptions, the flower number per node was unstable within every plant of both homozygous parents and hybrids (Table 1). The first filial progeny bore few (1-2) flowers, but detailed counts are available only for one combination, 'Lupinoid' × DTR (2016, Table 1). All the $F_{2}$ hybrids had either few- or manyflowered phenotype. Some of the hybrids occasionally produced four fully developed flowers per node, but we did not record any plants which had all flowering nodes producing more than three flowers.

To overcome such statistically uneasy situation, we attempted to evaluate this trait as qualitative rather than quantitative, so every individual plant was described as either few-flowered (those which develop single- and two-flowered I2s) or many-flowered (if any of axillary racemes on plant produced more than two flowers, Figure 1d).

\section{Results of bybrid analysis}

The results of these crosses are given in Table 2. In all three cases, the ratio was significantly closer to $13: 3$ rather than to $3: 1$ and $15: 1$ which are expected for monogenic and digenic polymeric inheritance, respectively. These results point at possibility of epistatic interaction of two genes controlling flower number in line DTR.

To test this hypothesis, we planted $18 \mathrm{~F}_{3}$ families obtained from self-pollination of individual $F_{2}$ plants from cross 'Lupinoid' $\times$ DTR. Among them, we found one family originating from a many-flowered $F_{2}$ plant, in which both few- and many-flowered individuals were

Table 1. Variations in flower number in two parental accessions and hybrids of crosses between them. Average \pm standard deviation are presented with min-max range in parentheses. Differences between parents are significant (Mann-Whitney test, $p<0.01$ ).

\begin{tabular}{lcccc}
\hline Parent 1 & Parent 2 & $F_{1}$ & Few-flowered & Many-flowered \\
\hline 'Lupinoid': $1.64 \pm 0.54(1-2)$ & DTR: $3.17 \pm 1.58(1-6)$ & $1.89 \pm 0.31(1-2)$ & $1.64 \pm 0.48(1-2)$ & $2.50 \pm 0.54(2-3)$ \\
'Shtambovyi': $1.44 \pm 0.50(1-2)$ & DTR: $2.35 \pm 0.59(1-3)$ & no data & $1.82 \pm 0.39(1-2)$ & $2.57 \pm 0.76(1-4)$ \\
\hline
\end{tabular}


Table 2. Segregation in $\mathrm{F}_{2}$ progenies from crosses between line DTR (many-flowered) and two-flowered varieties

\begin{tabular}{lcccc}
\hline F $_{2}$ population & $\begin{array}{c}\text { Observed ratio } \\
\text { (few- }: \text { many-flowered) }\end{array}$ & $\chi^{2} 3: 1$ & $\chi^{2} 15: 1$ & $\chi^{2} 13: 3$ \\
\hline 'Flagman' $\times$ DTR & $218: 51$ & 5,2354 & 74,1534 & 0,0078 \\
'Lupinoid' $\times$ DTR (2014) & $66: 9$ & 6,7600 & 4,2320 & 2,2400 \\
'Lupinoid' $\times$ DTR (2016) & $38: 4$ & 5,3651 & 0,7683 & 2,3468 \\
'Lupinoid' $\times$ DTR (2014+2016) & $104: 13$ & 12,0370 & 4,7185 & 4,4815 \\
'Shtambovyi' $\times$ DTR (2016) & $149: 44$ & 0,4991 & 90,1972 & 2,0759 \\
'Shtambovyi' $\times$ DTR (2009) & $105: 15$ & 10,0000 & 8,0000 & 3,0769 \\
'Shtambovyi' $\times$ DTR (2009+2016) & $254: 59$ & 6,3142 & 84,8053 & 0,0020 \\
\hline
\end{tabular}

present (16:11). Although sample size is too small for any statistical treatment, this case is highly informative for understanding mode of inheritance of studied trait. If the hypothesis of monogenic recessive character of many-flowered habit (nep nep, see Singer et al., 1999) is accepted, the many-flower plant could not produce fewflowered progeny via self-pollination. The same is true for digenic model with polymeric interaction (Lamprecht, 1947): the only possible genotype of manyflowered plant would be $f n f n$ fna fna, so no possibility to produce few-flowered progeny exists. Together with observations of 13:3 ratios in $F_{2}$, these data enable us to conclude that two genes, which exhibit a dominant epistasis interaction, govern a many-flowered state in the studied line DTR. If designations of genes remain the same as used by H. Lamprecht (Lamprecht, 1947) and propose that $F N$ is inhibitor, 13/16 of all $F_{2}$ plants would be few-flowered ( $F N ~ F N A, F N ~ f n a, f n f n a)$ while $3 / 16$ would be many-flowered $(f n F N A)$.

The genus Pisum is included into tribe Fabeae together with genera Lathyrus L. (vetchling), Vicia L. (vetch), Lens Mill. (lentil), and Vavilovia Fed. Except for the last listed genus, all other genera contain numerous species of outstanding agricultural value, serving as vegetable, dry grain, forage and ornamental cultures. It was earlier demonstrated that in most basal representatives of Lathyrus-Pisum-Vavilovia clade the single- or few-flowered I2s are usually associated with annual life form (Sinjushin \& Belyakova, 2015). In different lineages flower number increased sometimes reverting back to an initial single-flowered state. A close relation between pea and other species of Fabeae, exhibiting a wide range of variation of the discussed trait, may propose the existence of different mechanisms which alter flower number. In this connection, our results do not contradict previously existing facts but complement them. Epistatic interaction seems very reliable from the ontogenetic point of view, as normally proliferation of $\mathrm{I} 2$ is probably inhibited by certain gene(s). In mutants, this inhibition is lost resulting in prolonged proliferation of $\mathrm{I} 2$ and hence increased flower number. Some mutants of legume species normally having a single- or fewflowered axillary racemes are remarkable as having more flowers. For example, in $L$. sativus a chromosome aberration is associated with an increase of flower number per I2 (Talukdar, 2013). Possibly similar regulatory processes took place in different evolutionary lines of tribe Fabeae.

\section{Conclusions}

Our results evidence that at least in some pea accessions an increased (more than two) number of flowers per axillary raceme can be controlled by two genes which interact in an epistatic way.

We do not propose any new gene designations, as additional tests are required to uncover relation between many-flowered pea lines from different germplasm collections. Our results contribute to the diversity of genetic control of flower number in legumes and may be used for breeding programs.

\section{References}

Benlloch, R., Berbel, A., Ali, L., Gohari, G., Millán, T., \& Madueño, F. (2015). Genetic control of inflorescence architecture in legumes. Front. Plant Sci., 6, 543.

Hole, C. C., \& Hardwick, R. C. (1975). Development and control of the number of flowers per node in Pisum sativum L. Ann. Bot., 40, 707-722.

Lamprecht, H. (1947). The inheritance of the number of flowers per inflorescence and the origin of Pisum, illustrated by polymeric genes. Agri Hort. Genet., 5, 16-25.

Singer, S., Sollinger, J., Maki, S., Fishbach, J., Short, B., Reinke, C., Fick, J., Cox, L., McCall, A., \& Mullen, H. (1999). Inflorescence architecture: A developmental genetics approach. Bot. Rev., 65, 385 -410 .

Sinjushin, A. A., \& Belyakova, A. S. (2015). Ontogeny, variation and evolution of inflorescence in tribe Fabeae (Fabaceae) with special reference to genera Lathyrus, Pisum and Vavilovia. Flora, 211, 11-17.

Talukdar, D. (2013). Cytogenetics of a reciprocal translocation integrating distichous pedicel and tendril-less leaf mutations in Lathyrus sativus L. Caryologia, 66, 21-30. 


\section{Prilog genetskoj kontroli broja cvetova kod graška (Pisum sativum L.)}

\section{Andrey Sinjushin · Anna Liberzon}

Sažetak: Ovaj rad pruža nove podatke o genetskoj kontroli broja cvetova po bočnoj cvasti kod baštenskog graška (Pisum sativum L.). Ova karakteristika je od poljoprivredne i evolucione važnosti. Analizom ukrštanja zaključeno je da, pored prethodno predloženih modela monogenske recesivne i kumulativne polimerije, dva gena mogu kontrolisati određenu osobinu kada su u interakciji dominantne epistaze. Ovo znači da se višecvetne bočne grozdaste cvasti razvijaju na biljkama graška ako sadrže dominantni alel inhibirajućeg gena $(F N)$ ili dvostruko recesivne homozigote ( fn fn fna fna). $\mathrm{U} \mathrm{F}_{2}$ generaciji odnos 13:3 može se uočiti kroz preovladavanje višecvetnih biljaka.

Ključne reči: cvast, cvet, epistaza, genetska kontrola, grašak, Pisum, razvoj 